\title{
URGENSI PENERAPAN METODE DAN STRATEGI PEMBELAJARAN EFEKTIF DALAM PERKULIAHAN
}

\author{
Oleh: Achmad Musyahid*
}

\begin{abstract}
Effective teaching method and strategy is of great importance as this may influence the model and future of our educational system. Effective method and strategy of teaching has a number of strengths, particularly, in enhancing students' enthusiasm to learn, improving quality and student self confidence, and, in the end, leading to maximum outcome of learning. This teaching method and strategy may also encourage lecturers to be more competent and be well prepared before teaching process in the classroom.
\end{abstract}

KEYWORDS: Metode, strategi, pembelajaran efektif

DALAM membicarakan masalah pendidikan, Bangsa Indonesia dihadapkan pada permasalahan pendidikan yang bersifat tidak pasti, rumit, dan berliku-liku, apalagi jika dilihat dari segi sistem dan pelaksanaannya. Salah satu masalah yang dihadapi dunia pendidikan bangsa ini adalah lemahnya proses pembelajaran. ${ }^{1}$ Dalam proses pembelajaran, mahasiswa kurang didorong untuk mengembangkan kemampuan berpikir. Proses pembelajaran hanya diarahkan kepada kemampuan untuk menghapal informasi tanpa dituntut untuk memahami informasi tersebut dengan menghubungkannya dengan kehidupan sehari-hari. Pada akhirnya, mereka pintar secara teori, tetapi miskin aplikasi. ${ }^{2}$

Lemahnya proses pembelajaran yang dikembangkan dosen dewasa ini seperti yang dijelaskan di atas merupakan salah satu masalah yang dihadapi dunia pendidikan. Proses pembelajaran yang dilaksanakan tidak sesuai dengan kemampuan dosen, pengelolaan pembelajaran yang tidak merata berdasarkan latar belakang pendidikan dosen, serta kurangnya motivasi dan kecintaannya terhadap profesinya menyebabkan pengelolaan pembelajarannya dilakukan seadanya tanpa mempertimbangkan berbagai faktor yang dapat mempengaruhi keberhasilan proses pembelajaran. Hal inilah yang menjadi penyebab rendahnya kualitas mereka sehingga

*Magister dalam bidang Filsafat Hukum Islam pada Program Pascasarjana Institut Agama Islam Negeri (IAIN) Alauddin Makassar tahun 1999 ini adalah dosen tetap pada Fakultas Syariah dan Hukum Universitas Islam Negeri (UIN) Alauddin Makassar. 
mahasiswa sulit bersaing dan mereka tidak mampu mengaktualisasi-kan dirinya dalam masyarakat ilmiah maupun masyarakat umum.

Menyikapi persoalan di atas, maka dosen harus didorong untuk sungguh-sungguh melaksanakan pengelolaan pembelajarannya melalui perencanaan yang matang. Melalui standar proses pendidikan tersebut, setiap pengelola pendidikan dapat menentukan bagaimana proses pembelajaran itu dapat berlangsung dengan baik. Komponen yang selama ini dianggap sangat mempengaruhi proses pendidikan adalah dosen sebab dosen merupakan ujung tombak yang berhubungan langsung dengan mahasiswa sebagai subjek dan objek belajar. ${ }^{3}$

Bagaimanapun bagus dan idealnya kurikulum pendidikan, sarana, dan prasarana yang tersedia tanpa diimbangi dengan kemampuan dosen mengimplementasikan metode dan strategi pembelajaran efektif dalam perkuliahan, semua itu kurang berarti. Untuk mencapai standar proses pendidikan, sebaiknya dimulai dengan menganalisis dan bagaimana ia menerapkan metode dan strategi pembelajaran yang efektif dalam setiap perkuliahan.

\section{JENIS-JENIS METODE PEMBELAJARAN EFEKTIF}

Berikut akan dikemukakan beberapa jenis metode pembelajaran efektif yang dirangkum dalam berbagai bentuk.

\section{Metode Proyek atau Unit}

Metode proyek atau unit adalah cara penyajian pelajaran yang bertitik tolak dari suatu masalah kemudian dibahas dari berbagai segi yang berhubungan sehingga pemecahannnya secara keseluruhan dan bermakna. Penggunaan metode ini bertolak dari anggapan bahwa pemecahan masalah tidak akan tuntas bila tidak ditinjau dari berbagai segi. Dengan kata lain, pemecahan suatu masalah perlu melibatkan bukan hanya satu mata kuliah melainkan melibatkan berbagai mata kuliah yang ada kaitan dan kontribusinya sehingga setiap masalah dapat dipecahkan secara keseluruhan. ${ }^{4}$

\section{Metode Eksperimen atau Percobaan}

Metode eksperimen atau percobaan adalah cara penyajian pelajaran yang mengarahkan mahasiswa melakukan percobaan dengan mengalami dan membuktikan sendiri materi yang dipelajari. Dalam proses belajar ini, mahasiswa diberi kesempatan untuk mengalami sendiri, melakukan sendiri, mengikuti suatu proses, mengamati suatu objek, menganalisis, membuktikan, dan menarik kesimpulan sendiri mengenai suatu objek, keadaan, atau proses sesuatu. ${ }^{5}$ 


\section{Metode Pemberian Tugas dan Resitasi}

Metode pemberian tugas dan resitasi adalah cara penyajian bahan pelajaran dengan memberikan tugas tertentu agar mahasiswa melakukan kegiatan belajar yang kemudian harus dipertanggungjawabkan. Tugas yang diberikan oleh dosen dapat memicu atau mendorong mahasiswa memperdalam bahan yang telah dipelajari dan merangsang mereka untuk aktif belajar secara individual maupun kelompok. ${ }^{6}$

\section{Metode Diskusi}

Metode diskusi adalah metode pembelajaran yang menghadapkan mahasiswa pada suatu permasalahan. Tujuan utama metode ini adalah untuk memecahkan suatu permasalahan, menjawab pertanyaan, menambah dan memahami pengetahuan mahasiswa, serta untuk membuat suatu keputusan. Karena itu, diskusi bukanlah debat yang bersifat beradu argumentasi, tetapi bertukar pengalaman untuk menentukan keputusan tertentu secara bersama-sama. ${ }^{7}$

\section{Metode Sosiodrama dan Role Playing}

Metode sosiodrama dan role playing dapat dikatakan sama artinya dan dalam pemakaiannya sering disalahartikan. Sosiodrama pada dasarnya mendramatisasikan tingkah laku dalam hubungannya dengan masalah sosial. Tujuan yang diharapkan dengan metode ini adalah agar mahasiswa dapat menghayati dan menghargai perasaan orang lain dan menghargai tanggung jawab serta merangsang mahasiswa dalam kelas untuk berpikir dan memecahkan masalah. ${ }^{8}$

\section{Metode Demonstrasi}

Metode demostrasi adalah cara penyajian pelajaran dengan memperagakan atau mempertunjukkan kepada mahasiswa suatu proses, situasi atau benda tertentu yang sedang dipelajari baik sebenarnya atau tiruan yang disertai penjelasan lisan. Metode ini sangat baik bagi mahasiswa dalam penerimaan pelajaran karena lebih berkesan dan mendalam sehingga membentuk pengertian dengan baik dan sempurna. Mahasiswa juga dapat mengamati dan memperhatikan apa yang diperlihatkan selama pelajaran berlangsung. ${ }^{9}$

\section{Metode Problem Solving}

Metode problem solving atau metode pemecahan masalah bukan hanya sekedar metode mengajar. Ia juga merupakan suatu metode berpikir sebab dalam problem solving dapat digunakan metode-metode lainya yang 
dimulai dengan mencari data sampai kepada penarikan kesimpulan. Langkah-langkah penggunaan metode ini sebagai berikut: (a) Adanya masalah yang jelas untuk dipecahkan. Masalah ini harus tumbuh dari mahasiswa sesuai dengan taraf kemampuannya. (b) Mencari data atau keterangan yang dapat digunakan untuk memecahkan masalah yang muncul. Misalnya dengan jalan membaca buku-buku, meneliti, bertanya, dan berdiskusi. (c) Menetapkan jawaban sementara dari masalah tersebut. Dugaan jawaban tentu saja didasarkan pada data yang telah diperoleh pada langkah kedua di atas. (d) Menguji kebenaran jawaban sementara tersebut sehingga betul-betul yakin bahwa jawaban tersebut betul-betul cocok. (e) Menarik kesimpulan. Artinya mahasiswa harus sampai pada kesimpulan terakhir tentang jawaban dari masalah tadi. ${ }^{10}$

\section{Metode Karyawisata}

Metode karyawisata adalah metode yang mengajak mahasiswa keluar kelas untuk meninjau tempat tertentu atau objek yang mengandung sejarah. Ia bukan rekreasi, tetapi belajar atau memperdalam pelajarannya dengan melihat langsung faktanya. Kendatipun metode karya wisata banyak memiliki nilai non akademis, tujuan umum pendidikan dapat dicapai terutama mengenai wawasan dan pengalaman tentang dunia luar seperti museum tempat bersejarah dan sebagainya. ${ }^{11}$

\section{Metode Tanya Jawab}

Metode tanya jawab adalah cara penyajian pelajaran dalam bentuk pertanyaan yang harus dijawab terutama dari dosen kepada mahasiswa atau dari mahasiswa ke dosen. Metode ini dimaksudkan untuk merangsang kreativitas berpikir dan membimbing peserta didik dalam mencapai kebenaran. ${ }^{12}$

\section{Metode Latihan}

Metode latihan biasa juga disebut metode training merupakan suatu cara mengajar yang baik untuk menanamkan kebiasan-kebiasan tertentu. Selain itu, metode ini dapat juga digunakan untuk memperoleh suatu ketangkasan, ketepatan, kesempatan, dan keterampilan. ${ }^{13}$

\section{Metode Ceramah}

Metode ceramah adalah sebuah metode mengajar dengan cara menyampaikan informasi dan pengetahuan secara lisan kepada mahasiswa yang pada umumnya mengikuti secara pasif. Metode ceramah lazim pula disebut metode kuliah ataupun pidato. Metode ini merupakan sebuah cara melaksanakan pembelajaran secara monolog atau satu arah dan mahasiswa hanya menyimak dan mencatat. ${ }^{14}$ 


\section{Metode Kerja Kelompok}

Metode kerja kelompok atau kerja sama adalah upaya saling membantu antara dua orang atau lebih antara individu atau kelompok lainnya dalam melaksanakan tugas. Metode ini juga berguna untuk menyelesaikan problema yang dihadapi dan menggarap berbagai program yang bersifat prospektif guna mewujudkan kemaslahatan dan kesejahteraan bersama. ${ }^{15}$

\section{Metode Simulasi}

Metode simulasi dapat diartikan sebagai cara penyajian pengalaman belajar dengan menggunakan situasi tiruan untuk memahami konsep, prinsip atau keterampilan tertentu. Metode simulasi dapat digunakan sebagai metode mengajar dengan asumsi tidak semua metode pengajaran dapat dilakukan secara langsung pada objek yang sebenarnya.

\section{Metode Tutorial}

Metode tutorial dapat diberikan dengan bantuan tutor. Setelah mahasiswa diberikan bahan ajar, mereka diminta mempelajari bahan ajar tersebut dan pada bagian yang sulit dapat ditanyakan pada tutor.

\section{Metode Perumpamaan}

Metode perumpamaan digunakan untuk mengungkapkan suatu sifat dan hakikat dari realitas sesuatu. Perumpamaan dapat dilakukan dengan menggambarkan sesuatu dengan sesuatu yang lain yang serupa.

\section{Metode Pemahaman dan Penalaran}

Metode pemahaman dan penalaran ini dilakukan dengan membangkitkan akal dan kemampuan berpikir secara logis dalam mendata dan menginventarisasi masalah dengan cara memilah-milah, membuang mana yang salah, meluruskan yang bengkok dan mengambil yang benar.

\section{Metode Suri Teladan}

Metode suri teladan dapat menumbuhkan hasrat bagi orang lain untuk meniru atau mengikutinya, baik dalam hal pendidikan anak, maupun dalam kehidupan dan pergaulan sehari-hari. ${ }^{16}$

\section{Metode Pemberian Motivasi}

Motivasi adalah kekuatan yang mendorong kegiatan individu untuk melakukan suatu kegiatan dalam mencapai tujuan. ${ }^{17}$ Motivasi dipandang sebagai dorongan mental yang menggerakkan dan mengarahkan perilaku manusia termasuk perilaku belajar. Dalam motivasi terkandung adanya 
keinginan untuk mengaktifkan, menggerakkan, menyalurkan dan mengarahkan sikap dan prilaku individu belajar.

\section{Metode Praktek}

Metode praktek yaitu memberikan materi pendidikan baik dengan menggunakan alat atau benda dengan harapan anak didik atau mahasiswa menjadi mudah memahami materi pembelajaran sehingga dapat mempraktekkan materi yang dimaksud.

\section{Metode Pemberian Ampunan dan Bimbingan}

Metode pemberian ampuan dan bimbingan yang dilakukan dalam rangka memberi kesempatan kepada anak didik atau mahasiswa untuk memperbaiki tingkah lakunya dan mengembangkan dirinya.

\section{Metode Kisah}

Metode kisah adalah metode pembelajaran dengan memberikan kisah-kisah yang mengandung pesan-pesan tertentu. Al-Qur'an dan hadis banyak meredaksikan kisah untuk menyampaikan pesan-pesannya. Di antaranya kisah malaikat, para nabi, umat terkemuka pada zaman dahulu dan sebagainya. Dalam kisah tersebut banyak tersimpan nilai-nilai pedagogis religius yang memungkinkan mahasiswa mampu meresapinya dan mengambil banyak pelajaran berharga. ${ }^{18}$

\section{Metode Tulisan}

Metode tulisan adalah menggunakan huruf atau simbol dimaksudkan untuk mengetahui segala sesuatu yang sebelumnya belum diketahui. ${ }^{19}$

\section{JENIS-JENIS STRATEGI PEMBELAJARAN EFEKTIF}

Ada beberapa strategi pembelajaran yang dapat digunakan dalam proses pembelajaran. Rowntree mengelompokkan ke dalam strategi pembelajaran penemuan atau exposition-dicovery learning dan strategi pembelajaran kelompok, serta strategi pembelajaran individual atau groupsindividual learning, yaitu:

\section{Strategi Pembelajaran Ekspositori (SPE)}

Strategi pembelajaran ekspositori adalah strategi pembelajaran yang menekankan kepada proses penyampain materi secara verbal dari seorang dosen kepada sekolompok mahasiswa dengan maksud agar mahasiswa dapat menguasai materi kuliah secara optimal. Roy Killen menamakan 
strategi ekspositori dengan istilah strategi pembelajaran langsung atau direct instruction dan sering juga diistilahkan dengan strategi chalk and talk atau proses bertutur. ${ }^{20}$

\section{Strategi Pembelajaran Inkuiri}

Strategi pembelajaran inkuiri adalah strategi pembelajaran yang menekankan pada proses berpikir secara kritis dan analitis untuk mencari dan menemukan sendiri jawaban dari suatu masalah yang dipertanyakan. Proses berpikir itu sendiri biasanya dilakukan melalui tanya jawab antar dosen dan mahasiswa. Strategi pembalajaran ini sering juga dinamakan strategi heuristic yang berasal dari bahasa Yunani yaitu heuriskein yang berarti saya menemukan. ${ }^{21}$

\section{Strategi Pembelajaran Berbasis Masalah (SPBM)}

SPBM dapat diartikan sebagai rangkaian aktivitas pembelajaran yang menekankan kepada proses penyelesaian masalah yang dihadapi secara ilmiah. Ada tiga ciri utama dari SPBM, yaitu: (a) SPBM merupakan rangkaian aktivias pembelajaran. Artinya dalam implementasi SPBM, ada sejumlah kegiatan yang harus dilakukan oleh mahasiswa; (b) Aktivitas pembelajaran diarahkan untuk menyelesaikan masalah. SPBM menempatkan masalah sebagai kata kunci dari proses pembelajaran. Artinya bahwa tanpa masalah maka tidak mungkin ada proses pembelajaran; (c) Pemecahan masalah dilakukan dengan menggunakan pendekatan berpikir secara ilmiah.

\section{Strategi Pembelajaran Peningkatan Kemampuan Berpikir (SPPKB)}

Model strategi pembelajaran peningkatan kemampuan berpikir adalah model pembelajaran yang bertumpu kepada pengembangan kemampuan berpikir mahasiswa melalui penelaahan fakta-fakta atau pengalaman mahasiswa sebagai bahan untuk memecahkan masalah yang diajukan. ${ }^{22}$ Artinya, tujuan yang ingin dicapai oleh SPPKB adalah bukan sekedar mahasiswa dapat menguasai sejumlah materi pelajaran, akan tetapi bagaimana mahasiswa dapat mengembangkan gagasan-gagasan dan ide melalui kemampuan berbahasa secara verbal.

\section{Strategi Pembelajaran Kooperatif (SPK)}

Strategi pembelajaran kooperatif adalah salah satu model pembelajaran kelompok ${ }^{23}$ yang terdiri dari empat sampai enam orang yang mempunyai latar belakang kemampuan akademik, jenis kelamin, dan suku yang berbeda. Akhir-akhir ini, strategi pembelajaran kooperatif menjadi 
perhatian dan dianjurkan oleh ahli pendidikan untuk digunakan. Dalam hal ini, Slavin mengemukakan dua alasan: (a) Beberapa hasil penelitian membuktikan bahwa penggunaan pembelajaran kooperatif dapat meningkatkan prestasi belajar mahasiswa sekaligus dapat meningkatkan hubungan sosial, menumbuhkan sikap menerima kekurangan diri orang lain serta dapat meningkatkan harga diri; (b) Pembelajaran kooperatif dapat merealisasikan mahasiswa dalam belajar berpikir, memecahkan masalah, dan mengintegrasikan pengetahuan dengan keterampilan. ${ }^{24}$

\section{Strategi Pembelajaran Kontekstual}

Contextual Taching and Learning (CTL) adalah suatu strategi pembelajaran yang menekankan kepada proses keterlibatan mahasiswa secara penuh untuk menemukan materi yang dipelajari dan menghubungkannya dengan situasi kehidupan nyata sehingga mendorong mahasiswa untuk dapat menerapkannya dalam kehidupan mereka. ${ }^{25}$

Dari konsep tersebut ada tiga hal yang harus dipahami yaitu; CTL menekankan kepada proses keterlibatan mahasiswa untuk menemukan materi, CTL mendorong agar mahasiswa dapat menemukan hubungan antara materi yang dipelajari dengan situasi kehidupan nyata, CTL mendorong mahasiswa untuk dapat menerapkannya dalam kehidupan.

\section{Strategi Pembelajaran Afektif}

Strategi pembelajaran afektif memang berbeda dengan strategi pembelajaran kognitif dan keterampilan. Afektif berhubungan dengan nilai (value) yang sulit diukur oleh karena menyangkut kesadaran seseorang yang tumbuh dari dalam. Pada batasan tertentu, afeksi dapat muncul dalam kejadian behavioral akan tetapi penilaiannya untuk sampai kepada kesimpulan yang bisa dipertanggungjawabkan membutuhkan ketelitian dan observasi yang terus menerus. Hal ini tidaklah mudah dilakukan apalagi menilai perubahan sikap sebagai akibat dari proses pembelajaran yang dilakukan dosen di kampus.

Douglas Graham melihat empat faktor yang merupakan dasar kepatuhan seseorang terhadap nilai tertentu, yaitu: (a) Normativis atau kepatuhan pada norma-norma hukum. Selanjutnya dikatakan bahwa kepatuhan ini terdapat dalam tiga bentuk, yakni kepatuhan pada nilai atau norma itu sendiri, kepatuhan pada proses memperdulikan normanya sendiri, dan kepatuhan pada hasil dan tujuan yang diharapkannya dari peraturan itu; (b) Integralis atau kepatuhan yang didasarkan pada kesadaran dengan pertimbangan-pertimbangan rasional; (c) Fenomenalis atau kepatuhan berdasarkan suara hati atau kadar basa-basi; (d) Hedonis atau kepatuhan berdasarkan kepentingan diri sendiri. 26 
Sedangkan sikap adalah kecenderungan seseorang untuk menerima atau menolak suatu objek berdasarkan nilai yang dianggapnya baik atau tidak baik. Dengan demikian, belajar sikap berarti memperoleh kecenderungan untuk menerima atau menolak suatu objek berdasarkan penilain terhadap objek itu sebagai hal yang berguna atau berharga (sikap positif) dan tidak berharga atau tidak berguna (sikap negatif). Sikap merupakan suatu kemampuan internal yang sangat berperan dalam mengambil tindakan (action), lebih-lebih apabila terbuka berbagai kemungkinan untuk bertindak atau tersedia beberapa alternatif.

Setiap strategi pembelajaran sikap pada umumnya menghadapkan mahasiswa pada situasi yang mengandung konflik atau situasi yang problematis. Melalui situasi ini, diharapkan mahasiswa dapat mengambil keputusan berdasarkan nilai yang dianggapnya baik. Di bawah ini disajikan beberapa model strategi pembelajaran sikap. ${ }^{27}$

Model konsiderasi dikembangkan oleh Mc. Paul, seorang humanis. Paul menganggap bahwa pembentukan moral tidak sama dengan pengembangan kognitif yang rasional. Pembelajaran moral mahasiswa menurutnya adalah pembentukan kepribadian, bukan pengembangan intelektual. Olehnya itu, model ini menekankan kepada strategi pembelajaran yang dapat membentuk kepribadian. Tujuannya adalah agar mahasiswa menjadi manusia yang memiliki kepedulian terhadap orang lain, karena kebutuhan yang fundamental pada manusia adalah bergaul secara harmonis dengan orang lain, saling memberi dan menerima dengan penuh cinta dan kasih sayang. Dengan demikian, pembelajaran sikap pada dasarnya adalah membentuk mahasiswa agar dapat mengembangkan kemampuan untuk bisa hidup bersama secara harmonis, peduli, dan merasakan apa yang dirasakan orang lain.

Model pengembangan kognitif dikembangkan oleh Lowrence Kohlberg. Model ini diilhami oleh pemikiran John Dewey dan Jean Piaget yang berpendapat bahwa perkembangan manusia terjadi sebagai proses dari restrukturisasi kognitif yang berlangsung secara berangsur-angsur menurut urutan tertentu.

\section{PENUTUP}

Dari berbagai uraian di atas, dapat disimpulkan beberapa hal: Untuk mencapai hasil maksimal dari setiap pembelajaran dalam perkuliahan, setiap dosen harus menerapkan metode dan strategi pembelajaran efektif. Metode dan strategi pembelajaran efektif ini mempunyai kelebihan dalam 
mendorong dan meningkatkan kemampuan mahasiswa dalam proses belajar. Penerapan metode dan strategi pembelajaan efektif ini dengan sendirinya dapat mendorong para pengajar untuk meningkatkan kemampuannya dalam proses pembelajaran.

\section{CATATAN AKHIR:}

1. Konsep pembelajaran adalah suatu proses di mana lingkungan seseorang dengan sengaja dikelola untuk memungkinkan ia turut serta pada tingkah laku tertentu dalam kondisi khusus atau menghasilkan respon terhadap situasi tertentu, pembelajaran merupakan subset khusus dari pendidikan. Lihat Dimyati \& Mudjiono, Belajar dan Pembelajaran (Cet. III; Jakarta: Rineka Cipta, 2006,) h. 9-16.

2. Lihat Wina Sanjaya, Strategi Pembelajaran Berorientasi Standar Proses Pendidikan (Ed. I, Cet. II; Jakarta: Kencana Prenada Media Group, 2007), h. 1.

3. Lihat Mukhtar, Syamsu, dan Rusini, Pendidikan Anak Bangsa Pendidikan untuk Semuanya (Cet. I; Jakarta: PT. Nimas Multima, 2002), h. 68.

4. Lihat Syaiful Bahri Djamarah dan Aswan Zain, Strategi Belajar Mengajar (Ed. Revisi, Cet. III; Jakarta: Rineka Cipta, 2006), h. 83.

5. Saiful, Strategi Belajar Mengajar, h. 84. Bandingkan dengan Syaiful Sagala, Konsep dan Makna Pembelajaran (Cet. IV; Bandung: Alfabeta, 2006), h. 220.

6. Sagala, Konsep dan Makna Pembelajaran, h. 219.

7. Wina, Strategi Pembelajaran Berorientasi Standar Proses Pendidikan, h. 152-153. Lihat juga Pupuh Fathurrohman dan M. Sobry Sutikno, Strategi Belajar Mengajar Melalui Konsep Umum dan Islami (Cet. I; Bandung: PT. Refika Aditama 2007), h 62.

8. Bahri, Strategi Belajar Mengajar, h. 88.

9. Bahri, Strategi Belajar Mengajar, h. 90.

10. Bahri, Strategi Belajar Mengajar, h. 91-92.

11. Sagala, Konsep dan Makna Pembelajaran, h. 214.

12. Pupuh, Strategi Belajar Mengajar Melalui Konsep Umum dan Islami, h. 62

13. Sagala, Konsep dan Makna Pembelajaran, h 217.

14. Pupuh, Strategi Belajar Mengajar Melalui Konsep Umum dan Islami, h. 61.

15. Pupuh, Strategi Belajar Mengajar Melalui Konsep Umum dan Islami, h. 64.

16. Pupuh, Strategi Belajar Mengajar Melalui Konsep Umum dan Islami, h. 63.

17. Ada tiga komponen utama dalam motivasi yaitu; kebutuhan, dorongan dan tujuan. Kebutuhan terjadi bila individu merasa ada ketidakseimbangan antara apa yang ia miliki dan apa yang ia harapkan. Dorongan merupakan kekuatan mental yang berorientasi pada pemenuhan harapan atau pencapaian tujuan. Sedagkan tujuan adalah hal yang ingin dicapai oleh seorang individu, tujuan tersebut mengarahkan prilaku dalam hal ini prilaku belajar. Lihat Dimyati, Belajar dan Pembelajaran, h. 80-81.

18. Pupuh, Strategi Belajar Mengajar Melalui Konsep Umum dan Islami, h. 62.

19. Pupuh, Strategi Belajar Mengajar Melalui Konsep umum dan Islami, h. 64.

20. Wina, Strategi Pembelajaran Berorientasi Standar Proses Pendidikan, h. 177. 
21. Wina, Strategi Pembelajaran Berorientasi Standar Proses Pendidikan, h. 194.

22. Menurut Peter Reason, berpikir adalah proses mental seseorang yang lebih dari sekedar mengingat dan memahami . Mengingat dan memahami lebih besifat pasif dari pada kegiatan berpikir. Mengingat pada dasarnya hanya melibatkan usaha penyimpanan sesuatu yang telah dialami untuk suatu saat dikeluarkan kembali atas permintaan sedangkan memahami memerlukan pemerolehan apa yang didengar dan dibaca serta melihat keterkaitan antara aspek dalam memori. Berpikir adalah istilah yang lebih dari keduanya, berpikir menyebakan seseorang harus bergerak hingga di luar informasi yang didengarkan, misalnya kemampuan berpikir seseorang untuk menemukan solusi baru dari suatu persoalan yang dihadapi. Wina, Strategi Pembelajaran Berorientasi Standar Proses Pendidikan, h. 228.

23. Model pembelajaran kelompok adalah rangkaian kegiatan belajar yang dilakukan oleh mahasiswa dalam kelompok-kelompok tertentu untuk mencapai tujuan pembelajaran yang telah dirumuskan. Ada empat unsur penting dalam SPK yaitu; (1) adanya peserta dalam kelompok, (2) adanya aturan kelompok, (3) adanya upaya belajar setiap anggoa kelompok dan (4) adanya tujuan yang harus dicapai. Wina, Strategi Pembelajaran Berorientasi Standar Proses Pendidikan, h. 239.

24. Wina, Strategi Pembelajaran Berorientasi Standar Proses Pendidikan, h. 240.

25. Wina, Strategi Pembelajaran Berorientasi Standar Proses Pendidikan, h. 253.

26. Wina, Strategi Pembelajaran Berorientasi Standar Proses Pendidikan, h. 272-273.

27. Wina, Strategi Pembelajaran Berorientasi Standar Proses Pendidikan , h. 277-281.

\section{DAFTAR PUSTAKA:}

Bahri, Syaiful \& Aswan Zain. Strategi Belajar Mengajar. ed. Revisi, Cet. III; Jakarta: Rineka Cipta, 2006.

Dimyati \& Mudjiono. Belajar dan pembelajaran. Cet. III; Jakarta: Rineka Cipta, 2006.

Ekosusilo, Madyo. Pedoman Penulisan Karya Ilmiah Cet. III; Semarang: Effhar, 1999.

Fathurrohman, Pupuh, dan M. Sobry Sutikno. Strategi Belajar Mengajar Melalui Konsep Umum dan Islami. Cet. I; Bandung: PT. Refika Aditama, 2007.

Mukhtar, Syamsu \& Rusini. Pendidikan Anak Bangsa Pendidikan untuk Semuanya. Cet. I; Jakarta: PT. Nimas Multima, 2002.

Sanjaya, Wina. Strategi Pembelajaran Berorientasi Standar Proses Pendidikan. Ed I, Cet. II; Jakarta: Kencana Prenada Media Group, 2007.

Sagala, Syaiful. Konsep dan Makna Pembelajaran. Cet. IV; Bandung: Alfabeta, 2006.

Sadiman, Aries S. Media. Pendidikan, Pengertian, Pengembangan dan Pemanfaatannya. Ed. I, Cet. 3; Jakarta: PT. Raja Grafindo Persada, 2005. 